\title{
İktidar Aracı Olarak Seyir Amaçlı (Aleni) Fiziksel Anatomiden' Sosyal Anatomiye'2: İnsan Bedeni Üzerinden İktidarın Form Değiştiren Hikâyesi
}

\author{
ALİ TAŞ* \\ alitas@sakarya.edu.tr \\ ORCID ID: 0000-0002-7747-5333
}

\author{
OĞUZHAN ÖZTÜRK ** \\ oguzhanozturk@sakarya.edu.tr \\ ORCID ID: 0000-0001-7959-9535
}

\author{
UMUT ORHAN*** \\ umutorhan@sakarya.edu.tr \\ ORCID ID: 0000-0002-3460-035X
}

Öz: Bu çalışmanın amacı, Foucault'un iktidar olgusuna ilişkin açıklamalarından hareketle bireylerin disipline edilerek itaatkâr bir varlı̆ga dönüştürülmelerinde fiziksel ve sosyal aleni anatominin nasıl rol oynadıklarının izini sürmektir. Bu çerçevede, çalışmada, iktidar mekanizmalarının insanları itaatkâr birer varlı̆̆a dönüştüren zihinsel arka planı hangi insani duygular üzerinden inşa ettiği sorusuna cevap aranmıştır. Cevap aranan bir diğer soru da kendini gizleme zorunluluğunda olan iktidarın, anatominin farklı biçimleri üzerinden sağlamış olduğu hükmetme esnasında kendisini gizlemeyi nasıl başardığıdır. Çalışmadaki veriler dokuz psikiyatrist hekimle yapılan mülakatlar aracılığıyla toplanmıştır. Mülakatlar sonucunda elde edilen veriler fiziksel aleni anatominin korku ve utanç, sosyal aleni anatominin ise beğenilme, popüler olma, dişlanma ve hor görülme şeklindeki zihinsel karşılıkları üzerinden işleyen etkin iktidar araçları olarak önemli işlevler üstlendiklerine işaret etmektedir. Diğer bir bulgu da, bilimin iktidarın kendini gizlemede etkin bir rol oynadığına ve sosyal aleni anatomiyle iktidarın, hem bireye yönelik hükmetme alanının genişlediği hem de kendisini gizleme konusunda daha mahir bir beceriye ulaştı̆̆ yönündedir.

Anahtar kelimeler: İktidar, Foucault, Fiziksel aleni anatomi, Fiziksel sosyal anatomi.

\section{Giriş̧}

İktidar, sosyal bilimlerin en önemli çözümleme alanlarından birisi olarak kabul edilmektedir. Fenomenin böylesi ilgi toplamasının en önemli nedenlerinden biri, farklı kurumlar ve bu kurumlara ilişkin mekanizmalar üzerinden toplumsal düzlemdeki bütün ilişkilere sızarak bu ilişkileri belli bir grup, ideoloji ve çıkar odağının öngördü-

\footnotetext{
* Doç. Dr., Sakarya Üniversitesi, İşletme Fakültesi, İşletme Bölümü.

** Arş. Gör., Sakarya Üniversitesi, İşletme Fakültesi, İşletme Bölümü.

*** Arş. Gör., Sakarya Üniversitesi, İşletme Fakültesi, İşletme Bölümü.

1 Aleni fiziksel anatomi hem kapitalizmin hem de cerrahlığın ilk gelişim evrelerinde idam edilmiş suçuluların bedenleri üzerinde cerrahlar tarafından gerçekleştirilen ve seyir amaçlı bir rituele dönüşen beden incelemesidir. 2 Aleni sosyal anatomi sosyal medya paylaşımları aracılığı ile bireyin kendi özel yaşam alanına ilişkin paylaşımlarının farklı disiplinlere özgü profesyoneller ve toplumsal düzlemin diğer parçaları tarafından didik didik incelenmesidir.
} 
ğü ve istediği doğrultuda etkileyebilme becerisidir. Bu nedenle iktidar olgusu farklı düşünsel akımların temsilcisi olan düşünürlerin ortak odaklanma noktalarından bir tanesi olmuştur. Bu düşünürler içerisinde Foucault’un, olguya ilişskin açıklamalarının çok yönlülüğü ve olguya dair araçlara yönelik olarak ortaya koyduğu argümanlar setinin derinliği nedeniyle olgu üzerine odaklanan diğer düşünürlerden ayrı bir öneme sahip olduğu söylenebilir. Foucault "iktidar" olgusu ile bir devletin sinırları içerisinde yaşayan insanların bağımlılı̆̆ını garanti eden kurum ve toplu aygıtlar bütününü kast etmemektedir. Foucault’un iktidara dair açılamalarında, şiddetin aksine kural formunu taşıyan bir uyruklaştırma kipi olduğuna dair de bir imaya rastlanılmamaktadır. Foucault’un bizzat kendisi iktidar olgusundan anladığının bir öğe ya da bir grup tarafından bir başka grup üzerinde kullanılan ve etkileri birbirini izleyen türemelerle toplumsal düzlemin bütünü içinden geçen bir egemenlik sistemini de kast etmediğini ifade etmektedir. Foucault’a göre iktidar denildiğinde "uygulandıkları alana içkin olan ve kendi örgütlenmelerini kuran güç ilişkileri çokluğunu" anlamak gerekmektedir. Bu çerçevede iktidar sürekli tekrara dayalı, canlı cansız, kendi kendini yeniden üreten her şeyiyle böylesi bir hareketlilikten yola çıkarak beliren, bunların her birinden destek alan ve geri dönerek onları sabitleştirmeye çalışan genel bir sonuçtur. İktidar, her yerden doğabilme özelliğine sahip olduğu için her yerdedir. ${ }^{3}$ Foucault'un bu açıklamaları göz önüne alındığında aslında iktidardan hiçbir zaman değişmez, tanımlanmış, boyutlandırılmış ve tek yanlı bir olgu olarak bahsetmediği görülmektedir. ${ }^{4}$ Foucault, iktidar ilişkilerine odaklanarak iktidarı bu ilişkiler ağı üzerinden açıklama çabası içerisindedir. Foucault, iktidarın her yerde olduğunu, her yerde olmasının nedeni ise her yeri kapsadığı için değil her şeyden doğabildiği için her yerde olduğunu ifade ederek; iktidarı, çok farklı mekanizmalar üzerinden işleyen bir olgu olarak nitelendirmektedir. Bu değerlendirme temelinde Foucault, iktidar ilişkilerinin ve tekniklerinin delilikten suça, suçtan cinselliğe kadar en beklenmedik alanlara kadar yayıldığını ve iç içe geçtiğini ifade ederek toplumsal düzlemde bütün ilişkilere sızmış ve bütün ilişkileri etkileyebilen çok çeşitli iktidar mekanizmalarının olabileceğini öne sürmektedir.

Bu çalışmanın odak noktasını Foucault'un iktidar olgusuna ilişkin bu yöndeki açıklamaları oluşturmaktadır. Çalışmada Foucault'un "İktidar her yerdedir; her yeri kapsadiğı için değil, her yerden doğduğu için her yerdedir" șeklindeki vurgularından hareketle hem farklı iktidar mekanizmalarının varlığına, hem de bu farklı iktidar biçimlerinin toplumsal düzlemin bütün alanlarına sızarak insanların ve insan gruplarının davranışlarını nasıl etkilediklerine yönelik bir iz sürülmesi amaçlanmaktadır. İfade edilen tema çerçevesinde çalışmada, "iktidar mekanizmalarının insanları itaatkâr birer varllğa dönüştüren zihinsel arka planı hangi insani duygular üzerinden inşa ettiği” sorusuna cevap aranmıştır. Bu soruyla ilişkili olarak cevap aranan bir diğer soru da "kendini gizleme zorunluluğunda olan iktidarın, anatominin farklı biçimleri üzerinden sağlamış olduğu hükmetme esnasında kendisini gizlemeyi" nasıl başardığıdır. Bu sorular temelinde ilk olarak, kapitalizmin başlangıcı ve gelişmesinde önemli bir iktidar/iktidar mekanizması olduğu düşünülen "aleni anatominin" insan bede-

3 Michel Foucault, Cinselliğin Tarihi, çev., Hülya Uğur Tanrı̈ver, İstanbul: Ayrıntı Yayınları, 2012, s.69.

4 Judith Revel, Güncelliğin Bir Ontolojisi, çev., Kemal Atakay, İstanbul: Otonom Yayıncılık, 2006. 
ni üzerinden işleyen nasıl bir iktidar aracı olduğunun analizi yapılmaya çalışılmıştır. İkinci olarak ise, tarihsel süreçle birlikte değişen iktidar formlarına bağlı olarak "aleni fiziksel anatominin" yerini alan "aleni sosyal anatominin" iktidara özgü yeni bir araçsal form olarak bireyleri öngörülen şekilde disipline etmede nasıl bir araca dönüşebildiği açıklanmaya çalışılmıştır. İfade edilen kapsamda araştırma iki kısımdan oluşmaktadır. Birinci kısımda Foucault temelinde gerçekleştirilen iktidar-özne ve disipline etme mekanizmalarıyla beden ve iktidar (bedenin cezalandırılması üzerinden bireyin disiplini) incelemelerine yer verilmiştir. İkinci kısımda ise, hem aleni fiziksel anatominin hem de aleni sosyal anatominin disipline edilmek istenilen bireylerin zihinlerindeki karşılığı ve bu iki aracın bireyi disipline ederek onun kapitalizmin ön gördügü forma nasıl sokulduğuna dair psikiyatristler üzerinden toplanan verilerin analizine yer verilmiştir.

\section{Foucault'da İktidar-Özne ve Cezalandırma Üzerinden Disipline Etme}

Foucault’a göre iktidar bir toplumda kendi örgütlemelerini inşa eden güç ilişkilerinin toplamıdır. İktidar bu çerçevede ele alındığında, salt bir aygit ya da kurumlar topluluğu olarak nitelendirilemez. İktidar bazılarının ya da bazı grupların baştan sahip oldukları güç olarak da nitelendirilemez. İktidar elde edilen, bir alanın içinden koparılıp alınan ya da belli kişilerle paylaşılan bir şey de değildir. ${ }^{5}$ İktidar; kendine özgü belli kavram, kuram ve mekanizmalar içeren ve kendi üretmiş olduğu doğrular aracılığıyla söze yansıyan söylemler üzerinden oluşturulmuş kurallar, normlar, inanç sistemleri ve pratikler üzerinden işleyen bir alandır. ${ }^{6}$ İktidar her yerdedir. İktidarın her yerde olmasının nedeni ise her yeri kapsaması değildir. İktidar her yerden, her ilişkiden doğabildiği ve her mekanizma üzerinden işleyerek toplumsal ilişkilerin içkin bir özelliğine dönüştüğü için her yerdedir. ${ }^{7}$ Bir kişi ya da grubun bir başka kişi ya da grubu kendi istediği gibi düşünmeye ve davranmaya yönlendirebildiği her durumda iktidar söz konusudur. İktidarın işleyişi, bireysel ya da kolektif taraflar arasındaki bir ilişki olarak görülmemelidir. Foucault’a göre iktidar yalnızca edimde vardır. İktidar kendi başına özgürlüklerden vazgeçilmesi, sahip olunan hakların bir başka kişi ya da gruplara devredilmesi, tek tek herkesin sahip olduğu iktidarı birkaç kişiye emanet etmesi değildir. İktidar ilişkileri önceden var olan ya da durmadan yenilenen bir rızanın ürünü olabilir. İktidar, doğası gereği bir konsensüsün dışavurumu olarak nitelendirilemez ${ }^{8}$ Foucault'un iktidara dair açıklamaları temel alındığında; iktidarın değişmez, tanımlanmış ve tek yanlı bir varlık olmadığına ve iktidarı anlamada iktidar ilişkileri üzerine vurgu yaptığı söylenebilir. ${ }^{9}$

Foucault’a göre iktidar ilişkileri özneyi inşa etmekte, özneye şekil vermekte ve farklı pratikler ve mekanizmalar üzerinden öznenin hem yaratıcısı hem de sürekli yönlendiricisi olmaktadırlar. İnsan, iktidar ilişkileri tarafından kurulan bir öznedir. Foucault’a göre zaman içerisinde çeşitli mekanizmalar aracılığıyla nesneleştiri-

5 Foucault, Cinselliğin Tarihi.

6 Michel Foucault, Deliliğin Tarihi, çev., Mehmet Ali Kılıçbay, İstanbul: İmge Yayınevi, 2014.

7 Foucault, Cinselliğin Tarihi.

8 Foucault, Deliliğin Tarihi.

9 Revel, Güncelliğin Bir Ontolojisi. 
len insan, özne konumunu yitirerek, iktidar ilişkileri tarafından kurulan bir özne olarak kendi söyleminin kurgulayıcısı ve oluşturucusu olmaktan uzaklaşmış, aktif bir varlık olma özelliğini kaybetmiş ve pasif bir yapıya dönüşerek basit-pasif özne konumuna gelmiştir. Bu dönüşüm insanı iktidar ilişkilerine tabi olan itaatkâr bir varlık pozisyonuna getirmiştir. İnsan tarihsel süreçte o süreçlerin içkin özelliği olan iktidar ilişkileri tarafından bir özne olarak doğmuş, yine tarihsel süreç içerisinde iktidar ilişkileri tarafından bir özne olarak ortadan kaldırılacaktır. ${ }^{10}$ Foucault insanı geleneksel bir toplum düzeninden modern bir toplumsal düzene geçen özne olarak nitelemiştir. Foucault’a göre insan, bedeni ve kimliği iktidar ilişkileri tarafından inşa edilen bir varlıktır. Öznenin, iktidar ilişkileri tarafından dizayn edilen toplumsal ilişkiler içerisinde oluşturulan bir unsur olduğunu ileri süren Foucault, bireyin bir özne olarak oluşumunda iktidarın anahtar bir role sahip olduğunu ifade etmektedir. Bu doğrultuda bireyler toplumsal alandaki karmaşık, çoğul ve değişken iktidar araçlarına/mekanizmalarına boyun eğerek bahsedilen bu ilişkiler aracılı̆̆ıyla da bir özne konumuna gelmektedirler. Yani özne toplumsal düzlemde iktidar ağına hizmet eden sistemler içerisinde oluşturulmaktadır. Bu özelliği nedeniyle, özneyi, kendi oluşturulduğu toplumsal düzlemden ve iktidar ilişkileri ağından ayrı tutmak mümkün görünmemektedir. ${ }^{11}$

Foucault'un iktidar ve özne olgusuna ilişkin açıklamaları incelendiğinde "sorunsallaştırma eyleminin" ifade edilen olgulara dair açıklamalarının da son derece önemli olduğu görülmektedir. Foucault’a göre, insanın ön görülen bir biçimde özneye dönüştürülmesinde ve iktidar ağına özgü mekanizmalar aracilığıyla itaatkâr bir birey haline gelmesinde delilik, cinsellik, suç ve hastalık gibi sorunsallaştırma biçimlerinin ve bu sorunsallaştırmalara özgü politikaların önemli bir yeri bulunmaktadır. ${ }^{12}$

Foucault'un sorunsallaştırma eylemine konu olan olgulardan bir tanesi deliliktir. Delilik, insanın disipline edilerek onun eylem kiplerine yön veren bir olgu olarak düşünülmektedir. Foucault’a göre delilik paradoksal bir çemberle tarihsel süreçte farklı şekillerde evrilerek en sonunda akla uygunsuzluğun simgelendiği bir kapatma uygulamasının tek nedeni olarak ortaya çıkmıştır. Delilik üzerinden yapılan kapatma eylemi iktidarın gücünün simgesidir. İktidar, delilik ve delilik temelli gerçekleşen kapatma eylemi üzerinden kendi arzu ettiği özne ve nesne imgesini yaratmakta ve bunu kalıcı kılmaktadır. Delilik, iktidarın kendi hükmetme niyeti içindeki keyfiliğinin simgesi ve bu kör keyfiliğin meşrulaştırılmasında kullanılan önemli bir olgu olmuştur. ${ }^{13}$ Delilik, kendi tarihsel gerçekliğinin oluşumu içerisinde belli bir anda kendini akıl hastası olarak bir pozitiflik tarzı içinde bir yabancılaşma bilgisini mümkün kılmıştır ${ }^{14}$ Deliler, kuralları iktidar tarafından belirlenmiş bir dünyanın bu kurallara uymayan aylakları dışlamada ve onları birer yabancı olarak niteleyerek kapama yoluyla öte bir dünyaya gönderilenlerdir. Bir başka ifadeyle, delilik akıl dışı olandır. Akıl, kendisini tanınır ve görünür kılmak için kendi dışında kalanları

10 Michel Foucault, Özne ve İktidar, çev., Işık Ergüden, Osman Akınhay, İstanbul: Ayrıntı Yayınevi, 2014. 11 Vedat Çelebi, “Michel Foucault’da Bilgi İktidar ve Özne İlişkisi”, Sosyal ve Beşeri Bilimler Degisi, 5/1 (2013). 12 Gülay Özdemir Akgündüz, "Foucault’da İktidar ve Beden İlişkisi”, Akademik Bakış Dergisi, 38 (2013).

13 Foucault, Özne ve İktidar, s.45.

14 Foucault, Özne ve İktidar, s.126. 
ötekileştirmekte ve bu ötekileştirme üzerinden kendi varlığını koruyarak iktidarın uygun gördügü düzlemin inşasına olanak tanımaktadır ${ }^{15}$ Delilik başta olmak üzere akıldışılık olarak nitelendirilen bütün ötekiler (eş cinseller, fahişeler vs.) toplumdan farklı iktidar tarafından biçimlendirilmesi mümkün olmamış kişilerdir. Ayrıca bu kişiler aklın hükmetmesine tabi olmadıkları için kapatılım/gözetim altında tutularak iktidarın hâkim normalleştirme söyleminin bir parçasına dönüşmüşlerdir. Bu çerçevede delileri kapatmak için kullanılan tımarhaneler ve diğer yeti yetimi olanlar için inşa edilen hastaneler, deliler başta olmak üzere bütün yeti yitimi olanları temizlemek ve mevcut düzlemin kurallarına uymayanların konularak iktidara ait dünyanın temizlenmesi için kullanılan yerlerdir. İktidar, akıl dışı olarak nitelendirmiş olduğu bütün ötekiler üzerinden kendisi için “ideal tipi” tanımlamaktadır. Burada akıl dışı olarak nitelendirilenlerin bütün ötekilerin kapatıldığı kapatma kurumlarına dair bir açıklama yapmak gerekmektedir.

Foucault’un "büyük kapatılma” olarak kavramsallaştırdığı iktidarın normal dışı olarak nitelendirdiği yeti yetimi olanlar için inşa edilen kapatma kurumları, yeti yetimi olanların normallere ait olan toplumsal düzlemden soyutlandırılarak zorunlu iskân ettirildikleri kurumlardır. ${ }^{16}$ Aslında kapatma ve kapatmaya ilişkin kurumlar sadece yeti yitimine uğramış bireyleri toplumdan soyutlama işlevi görmemektedirler. Bu kurumlar normal dışı olarak kabul edilenleri bir yandan toplumdan soyutlayan mekânlar iken, diğer yandan da normal olmayanları tedavi etme veya cezalandırma yönünde de bir işlev üstlenmektedirler. Burada cezalandırma olgusuna dair ayrı bir parantez açmak gerekmektedir. Çünkü cezalandırma mekanizması üzerinden işleyen disiplin altına alma ve bireylerin tabi olması bu çalışmanın odak noktası göz önüne alındığında oldukça önemli görünmektedir. Cezalandırma bir yandan normal dışı davranan bireylerin kendilerinin ya soyutlanması ya da disipline edilmeleriyle sonuçlanan bir iktidar uygulamasıyken, diğer yandan da bu cezalandırmalar üzerinden oluşturulan izleme, aktarma ve gösterme mekanizmalarıyla diğer bireyleri normal dışı davranılmasının ne kadar kötü bir durum olduğunu, normal dışı olmanın sonuçlarının ne derece vahim, katlanılması zor sonuçlar ortaya çıkardığını duyurarak ve göstererek onları normalleştirmede kullanılan bir başka mekanizma oluşturulmasına olanak tanımaktadır. İşte çalışmanın odak noktasını oluşturan "hem fiziksel hem de sosyal aleni anatomi” böylesi bir mekanizma olarak kabul edilebilir.

Foucault'un sorunsallaştırma eylemine konu olan bir diğer olgu da cezalandırmadır. Cezalandırma, Foucault tarafından en önemli 1slah-disipline etme mekanizması olarak yorumlanmaktadır. Foucault’a göre, bir ıslah mekanizması olan cezalandırma sanatı disiplinsel iktidar rejiminde ne kefareti ne de tam olarak bastırmayı hedef almaktadır. Cezalandırmanın birbirinden ayrı beş farklı işlevi olduğu ifade edilmektedir. Bunlardan ilki bireye özgü eylemleri, performansları, hal ve gidişleri aynı zaman dilimi içerisinde hem birer kıyaslama alanı hem de takip edilecek kuralın ilkesi konumunda olan bir bütün temel alınarak değerlendirmektir. Cezalandırmaya yüklenen

15 Foucault, Deliliğin Tarihi.

16 Aydın Kızılaslan vd., "Yeti Yitimi Modellerinin Tarihsel Gelişimi”, İzzet Baysal Üniversitesi Eğitim Fakültesi Dergisi, 16/1 (2015). 
ikinci işlev ise işlevsel bir farklılaştırmayla ilgilidir. Burada işlevsel farklılaştırmayla ifade edilmek istenilen, kuralın ister en düşük eşik isterse ortalama veya yaklaşılması gereken optimum olarak işletilsin işlevinde farklılaştırılmasıdır. Cezalandırmaya ilişkin biçilen diğer bir işlev ise bireyin kapasitesine ilişkin programlamaya yöneliktir. Burada ifade edilmek istenen bireyin kapasitesini, düzeyini, cinsini miktarsal terimlerle ölçmek ve değer terimleriyle hiyerarşik hale getirmektir. Burada bireyin kapasitesine ilişkin olarak bu kapasitenin sistem için sağladığı katkı temel alınarak bir değerleme kastedilmektedir. Cezalandırmaya yüklenen dördüncü anlam bireyin kapasitesine yönelik olarak yapılan bir değerlemenin devamı niteliğindedir. Burada cezalandırmaya yüklenen dördüncü işlev gerçekleştirilmeye niyetlenen bir uygunluğun zorlamasını bireyin kapasitesine yönelik değerlendirici ölçü boyunca işletmekle/ oynatmakla ilgilidir. Cezalandırmaya yüklenen beşinci ve son işlev ise normalleştirmeye yöneliktir. Burada cezalandırmanın yerine getirdiği işlev Foucault’un ifadesiyle "tüm farklılıklara göre olan farklılığı, anormalin dış sınırını tanımlayacak hududu çizmektir”. Aslında cezalandırmanın burada ifade edilen bütün işlevleri anormalin dış sınırını çizerek normalleştirmeye yöneliktir. Bu yönüyle cezalandırma kıyaslama yapmakta, farklılaştırmakta, türdeş hale getirmekte ve dişlamaktadır. Cezalandırmaya yönelik olarak ifade edilen bu işlevlerin tamamının disipline edilerek "normalleştirme" şeklinde ifade edilebilecek tek bir sonucu bulunmaktadır.

Aslında Foucault tarafından belirlenmiş olan iktidar ilişkilerinin ilk homojen diziminin disiplin ve/veya disipline etme biçimleri olduğu görülmektedir. Bu çerçevede Foucault belli bir tarihsel dönemi temel alarak bir takım iktidar uygulama formunun ayrıntılı tasvirini yapmaktadır. Foucault, tasvir etmiş olduğu bu iktidar formlarına disiplinler adını vermektedir. Disiplinler olarak nitelendirilen bu formların temel özelliği değişik pozisyonlara göre uygulamaya geçirilen zorlayıcı bir grup teknikler olmasıdır. Bu teknikler aracılığıyla bireylere sistematik bir çerçeve dayatılmakta ve dayatılan bu çerçeveler üzerinden bireyler uzamsal ve zamansal olarak ele geçirilebilir hale gelmektedirler. Disiplinlerin doğduğu dönemle insan bedeni sanatının ortaya çıktığı dönemler paralellik arz etmektedir. Disiplinler açısından insan bedeniyle ilgilenmek veya disiplin tekniklerinin odak noktasının insan bedeni olması bedene ilişkin beceri ve yetileri daha uysal ve itaatkar kılarak arttırmak amacı taşımamaktadır. Burada disiplinler ve disiplinlere özgü tekniklerin temel noktası insanın uysallığı ve yararlılığını sağlamaktır. Burada disiplin üzerinden insan bir yandan daha uysal hale getirilirken, diğer yandan da sistem için ön görülen yararlılık düzeyine taşınmaya çalışılmaktadır. ${ }^{17}$

Buraya kadar ifade edilenlerden anlaşılacağı üzere bireyi disipline ederek bireyin ön görülen şekilde normalleştirilmesinde cezalandırma ve cezalandırmaya ilişkin mekanizmaların odak noktalarından birini “insan bedeni” oluşturmaktadır. İktidarın kurgulamış olduğu ve işler kıldığ mekanizmalar büyük oranda insan bedeni üzerinden yürütülmektedir. Bu durumda beden, iktidar, cezalandırma ve disipline etme arasındaki ilişkiye dair ayrı bir açıklama yapmak gerekmektedir. 


\section{Beden ve İktidar- Bedenin Cezalandırılması Üzerinden Disipline Edilerek Bireyin Normalleştirilmesi}

İnsan bedeninin, iktidarın özneyi kurma (itaatkâr ve yararlı bireyler yetiştirme) sürecinde ele alınması gerektiği gözlenmektedir. Çünkü, cezalandırma ve kapama üzerinden işlerlik kazanan disipline etme mekanizmalarının tamamının odak noktasında insan bedeni bulunmaktadır. Foucault beden ve iktidar ilişkisini biyo iktidar ve biyo politik üzerinden açıklamaktadır. Foucault’a göre, iktidarın beden üzerindeki kontrol biçimi 17. yüzyıldan itibaren biyo iktidar ve biyo politik olmak üzere iki fark1 biçimde gelişmiştir. Foucault'un ortaya koyduğu beden iktidar ilişkisine yönelik iki farklı kavramı birbirinin zıttı ya da karşıtı iktidar biçimlerini ifade ediyor şeklinde yorumlamak doğru değildir. Nitekim Foucault, biyo iktidar ile biyo politiğin birbirinin karşı savı niteliğinde olmadığını ifade etmiştir. Foucault’a göre, biyo iktidar ve biyo politik bir ara bağıntı kümesinin bir birine bağlamış olduğu iki gelişim boyutunu ifade etmektedirler. ${ }^{18}$ Bir başka ifadeyle, biyo iktidar ve biyo politik kutupları beden üzerinde kurulan iktidarın iki farklı formunu ifade etmektedir. Biyo iktidar bedeni makine olarak merkeze almaktadır. Burada iktidara özgü yöntemlerle bedenin terbiyesi, yeteneklerinin arttırılması, güçlerinin ortaya çıkartılması, itaatkârlığın sağlanmasıyla bedenin etkili ve ekonomik kontrol sistemleriyle entegre olması sağlanmaktadır ${ }^{19}$ Bir başka ifadeyle, biyo-iktidar bireyin bedeni üzerinde uygulanan disiplinci iktidar modeli olarak nitelendirilmektedir. Bu niteleme temelinde disiplinci biçim (biyo iktidar formu), bireyleri sorunsallaştırma ve bu sorunsallaştırmaya bağlı olarak inşa edilen kapatma pratikleri üzerine inşa edilen mekanizmalar aracılığıyla bireyi toplumsal süreçlere uyumlu hale getirerek, istenilen insan kalıplarını ortaya çıkartmıştır. Birey, biyo iktidara özgü mekanizma ve işleyişler aracılığıyla içten fethedilmekte ve iktidarı içselleştirerek kurgulanmış sistemin dışına çıkma ihtimali olmayan bir öğeye dönüşmektedir ${ }^{20}$ Liberalizmin doğuşuyla birlikte beden üzerindeki iktidar biçimi form değiştirmiş ve yeni bir form olarak düzenleyici iktidar modeli olan "biyo politika" biçimini almıştır. Biyo politikada yine beden üzerinden işlemekte

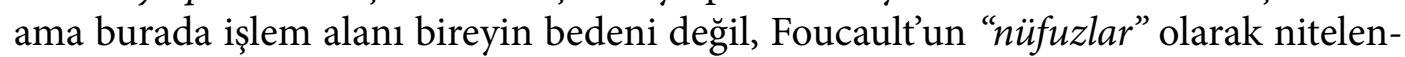
dirdiği "şeyin” beden üzerinden işlerlik kazanması durumudur. Burada bireyleri birer birer nesneleştiren iktidar modelinden, nüfuza yönelen bir iktidar modeline geçiş söz konusudur. Bu dönüşümle birlikte "nüfuzlar" aynı bireyler gibi iktidar ilişkilerinin iktidara özgü yeni mekanizmalar üzerinden insanlara ve insanların yaşamlarına uygulanmalarının ürünü haline gelmişlerdir. Bu durumla birlikte nüfuzlar artık insanların yalnızca itaatkârlık ve sistem içerisinde yararlılıklarının değil, yaşamlarının bütün alanlarının ele geçirilip bir niyet doğrultusunda kullanılabilmeleri için iktidarın zorunlu birer icadı olmuşlardır. Burada yaşamın yüceleştirilmesi, sağlıklı yaşam, sağlık derecesi, yaşam süreleri ve doğum-ölüm oranları gibi değişkenlere yapılan vurgular üzerinden sağlıklı ve zinde bir kitle ortaya çıkartmak ve bu kitleyi kapitalist düzlem içerisinde üretime yönlendirmek amaçlanmaktadır. Biyo politika

18 Foucault, Özne ve İktidar.

19 Foucault, Özne ve İktidar, s.102.

20 Çağrı Uluğer, "Yaşam ve Ölüm Arasında Sallanan İktidar Sarkacı: Biyo Politika”, Mesele Dergisi, 88 (2014). 
formunda iktidar tıp, psikiyatri, hukuk gibi alanlar aracıllğıyla geliştirilen normlarla olmasi-olmaması gerekenler ve yapılmasi-yapılmaması gerekenleri topluma dayatır hale gelmektedir. İktidar, böylece toplumsal düzlemde normal ve anormal olanın ne olduğunu belirleyerek ve bireylerin bu normalleri ve anormalleri içselleştirmesini sağlayarak Foucault’un "büyükk kapatılma" adını verdiği düzlemi inşa etmektedir. ${ }^{21}$

İktidar, biyo iktidardan biyo politikaya yönelik gerçekleşen form değişimiyle birlikte zaman içerisinde kendisine yeni mekanizmalar ve sistemler yaratıp yenilenmekte; bu sistem ve mekanizmalar üzerinden geliştirmiş olduğu söylemlerle bireyleri disipline ederek kendi düzlemi içerisinde tutma niyetini gerçekleştirmektedir. Bilişim çağına geçişle birlikte ise iktidarın artık sadece politik, ekonomik, sağlık ve kültürel kurumlar üzerinden işleyen mekanizmalar temelinde bir söylem geliştirmediği, egemen anlamlandırmalar ve davranışlar yoluyla bizzat öznelere odaklanarak Guattarỉnin tabiriyle onları zehirlediği iddia edilmektedir. ${ }^{22}$

\section{Araştırmanın Yöntemi}

Araştırmanın giriş kısmında da belirtildiği gibi bu çalışmada "iktidar mekanizmalarının insanları disipline ederek itaatkâr birer varlığa dönüştüren zihinsel arka planı hangi insani duygular üzerinden inşa ettiği" sorusuna cevap aranmıştır. Bu soruyla ilişkili olarak cevap aranan bir diğer soruda "kendini gizleme zorunluluğunda olan iktidarın, anatominin farklı biçimleri üzerinden sağlamış olduğu hükmetme esnasında kendisini gizlemeyi" nasıl başardığıdır. Foucault'un biyo iktidar ve biyo politika formları üzerinden zaman içerisinde iktidarın aldığı formlara yönelik açılamaları göz önüne alındığında, belirtilen odakta bir araştırmanın ne derece orijinal, gerekli ya da anlamlı olduğuna dair bir sorgulama olabilir. Ancak bu araştırmada yukarıda belirtilen amaç çerçevesinde tam olarak niyetlenen şey, iktidar tarafından ortaya konulan mekanizmaların iktidarın tek hedefi konumunda olan bireyleri disipline etmeyi nasıl başardığına yine iktidara özgü bir mekanizma olan psikiyatri kurumunun en önemli öğesi olan psikiyatristler üzerinden cevap aramaktır. Bir başka ifadeyle, araştırmada bir yandan iktidara özgü mekanizmaların zaman içerisinde nasıl değiştiğine fiziksel ve sosyal anatomi temel alınarak ulaşılan veriler üzerinden somut açıklamalar yapmak hedeflenirken, diğer yandan da iktidarın form değiştiren mekanizmalar aracıllğıyla oluşturduğu normlar üzerinden geliştirmiş olduğu söylemin, bireyler tarafından içselleştirilerek birey üzerinde nasıl bir hâkimiyet kurduğu yine bir iktidar kurumunun öğeleri üzerinden toplanan verilerle açıklanmaya çalışılmıştır.

Araştırmada bir iktidar mekanizması ve/veya aracı olarak anatominin seçilmesinin temel nedeni "anatominin" farklı iktidar formlarının ortak aracı olarak karşımıza çıkmasıdır. Fiziksel anatomi zaman içerisinde toplumsal düzlemde yaşanan gelişmeler ve bu gelişmeler temelinde iktidarın aldığı yeni formla birlikte sosyal anatomiye dönüşmüştür. Anatomiye ilişsin bahsedilen bu dönüşüm anatomi temel alınarak iktidarın nasıl form değiştirerek amacına ulaştı̆̆ını, derinleştiğini ve yumuşak hale gelerek kendini gizlemede nasıl mahir bir hal kazandığını göstermek açısından ol-

21 Cihan Palancı, "Biyo İktidarı Siponaza ile Okumak”, Toplum ve Demokrasi, 10/21 (2016).

22 Felix Guattari, Kaçış Çizgileri, çev., Işık Ergüden, İstanbul: Otonom Yayıncılık, 2014. 
dukça önemli görülmektedir. Ancak araştırmada bu yolla niyetlenilen şey, iktidarın toplumsal düzlemdeki bütün ilişkilere sızmış olmasına rağmen kendini hissettirmemeyi/gizlemeyi aleni sosyal ve fiziksel anatomi araçlarını işletenler üzerinden nasıl başardığını gözler önüne sermektir. İktidarın kendini nasıl gizleyebildiği sorusuna ilişkin analiz oldukça önemlidir. Çünkü Foucault’a göre iktidar ancak kendisine ait bir bölümü maskeleyebildiği/gizleyebildiği durumda normal görülebilir. Bu durumda iktidarın başarısı kendine özgü mekanizmaların ne kadarını saklayabildiğiyle doğru orantılıdır. Giz, gizlenme, kendini hissettirmeme iktidarın işlerliği için başarmak zorunda olduğu en önemli zorunluluktur. ${ }^{23}$

Araştırmada bir iktidar kurumu ve mekanizması olarak nitelendirilen psikiyatri kurumunun öğeleri olan psikiyatristler üzerinden verinin toplanmasının bir çelişki olacağı düşünülebilir. Araştırmada iktidara özgü bir kurum olarak psikiyatrinin seçilmesi ve verilerin psikiyatristler üzerinde toplanmasının temel nedeni, araştırmanın iktidar mekanizmalarının bireyin zihninde ne tür karşılıklar bulduğu ve iktidar tarafından oluşturulan normların bireyde nasıl içselleştiğinin analiz edilmesi yönündeki amacıyla ilgilidir. Bahsedilen düzlemde bir analiz doğrudan psikiyatri kurumunun alanıyla ilgilidir.

Yapılan açıklamalar çerçevesinde ihtiyaç duyulan verilerin toplanmasında "mülakat” tekniği kullanılmıştır. Araştırmada mülakat yapılacak psikiyatristlere ulaşmak için ilk aşamada şahsi tanışıklığın olduğu iki psikiyatristle irtibata geçilmiştir. Bu iki psikiyatristin önerileri ve onlardan alınan bilgiler doğrultusunda, psikiyatristler ve doktorlarla ilgili çalışma alanı bulunan iki derneğin üyeleriyle iletişime geçilmiştir. Derneklerin üyesi olan psikiyatristlerle kurulan iletişim sonucunda ilk olarak 26 psikiyatrist mülakat isteğine olumlu cevap vermiştir. Mülakat isteğine cevap veren 26 psikiyatristin eğitim aldıkları okullar, bilimsel yayınları ve ilgi alanlarına yönelik olarak hem internet kaynakları üzerinden, hem de kendileriyle yapılan ilk mülakatlarla veriler derlenmiştir. Mülakat talebine olumlu yanıt veren 26 psikiyatrist hakkında toplanan veriler araştırmacı tarafından incelendikten sonra araştırmada ihtiyaç duyulan verinin toplanmasına en üst düzeyde katkı sağlayacı düşünülen 11 psikiyatrist belirlenmiştir. Belirlenen 11 psikiyatristten ikisi araştırma konusunun kendileri için çok zorlayıcı olduğunu ve bu konuda özel bir çalışma yapmaları gerektiğini ancak böylesi bir çalışma için vakitleri olmadığını ifade ederek ilk mülakatlar sonrasındaki veri paylaşım sürecine katılamayacaklarını ifade etmişlerdir. Bu nedenle 9 psikiyatristle mülakatlara devam edilmiştir. 9 psikiyatristin her biriyle 3 er kez mülakat gerçekleştirilmiş her bir mülakat ortalama 2 saat sürmüş̧ür. Veri toplama süreci yaklaş1k olarak 2 ay (50 gün) sürmüştür.

\section{Mülakat Yapılacak Kişilerin Belirlenmesinde İzlenen Yol}

Veri toplama yöntemi olarak mülakat tekniğinin kullanıldığ 1 araştırmalarda en önemli karar aşamalarından bir tanesini mülakatların gerçekleştirilecek kişilerin belirlenmesi oluşturmaktadır. Çünkü bilimsel bir araştırmada katılımcıların sahip oldukları niteliklerle kendileri üzerinden ulaşılmaya çalışılan veriler arasında bir

23 Foucault, Cinselliğin Tarihi, s.65. 
uyumun olması çok önemlidir. Bu nedenle bu çalışmada mülakat yapılacak olan psikiyatristler belirlenirken araştırmaya yön veren sorular temel alınarak bu sorular temelinde ihtiyaç duyulan verilerin hangi niteliklere sahip psikiyatrist hekimler üzerinden toplanabileceği sorusu temel alınmıştır. Bu noktada, ilk olarak, mülakat talebimize olumlu dönüş yapan 26 psikiyatrist hekimin biyografileri internet üzerinden incelenmiştir. Daha sonra ilgili hekimler ziyaret edilmiş ve kendilerine araştırma konusu hakkında bilgi verilmiştir. Bu ziyaretler esnasında kendilerine kendi alanları dışında felsefe, sosyoloji ve ekonomi temalı eğitimlerle programlara katılıp katılmadıkları ve ifade edilen alanlarda düzenli olarak takip ettikleri bir yayın olup

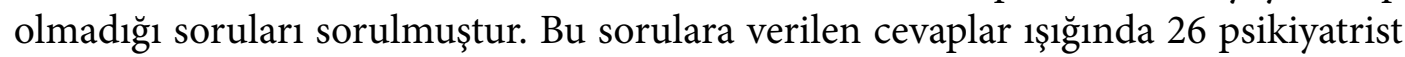
hekim arasından 3 tanesinin Türk Felsefe Derneği (TUFED) tarafından çıkartılan Felsefe Dünyası isimli e-dergiyi düzenli olarak takip ettikleri (adı geçen derginin bazı sayılarında iktidar konulu çalışmalar bulunmaktadır), 4 psikiyatrist hekimin ise her yıl düzenli olarak bir belediye tarafından düzenlenen felsefe seminerlerine katıldıkları ve felsefe okumaları yaptıkları, 5 psikiyatrist hekimin ise felsefe ve sosyolojiye yoğun bir ilgi duydukları mümkün olduğunca felsefe okumaları yaptıklarına dair verilere ulaşılmıştır. Bu veriler ışı̆̆ında, mülakat talebine olumlu cevap veren 26 psikiyatrist hekimin arasında ifade edilen özelliklere sahip 11 tanesinin araştırma için ihtiyaç duyulan verilerin toplanmasında yüksek katkı sağlayacak kişiler olacağ düşünülmüştür. (15 psikiyatrist hekimle ise araştırma konusuna çok uzak olmaları nedeniyle ilk mülakatlardan sonra araştırma konusu temelinde mülakatlar yapılmamıştır. Daha önce de ifade edilen biçimde belirlenen 11 psikiyatrist hekimden iki tanesi ise, araştırma konusuyla ilgili olarak özel bir araştırma/okuma yapmaları gerektiğini bunun için ise vakitleri olmadığını ifade ederek kendileriyle yapılan ikinci mülakattan sonra veri toplama sürecine dâhil olamayacaklarını belirtmişlerdir. 9 hekimle yapılan mülakatlardan ise 7’si değerlendirmeye alınmıştır).

\section{Veri Toplama Süreci (Mülakatlar ve Mülakatlarda Sorulan Sorular)}

Mülakat süreci ve mülakatlarda sorulan sorulara geçmeden önce araştırmanın tasarlanması esnasından yaşanan ve araştırmanın tasarımında son derece önemli bir şekillendirici olan bazı konularla ilgili olarak açıklama yapmanın ilgili süreçler açısından oldukça önemli olduğu düşünülmektedir. Bir belediye tarafından düzenlenen Felsefe Akademisi esnasında psikiyatrist hekim olan üç kişiye "bir iktidar aracı olarak seyir amaçlı fiziksel anatomi” teması altında bilimsel bir çalışmanın tasarlanmak istendiğinden bahsedilmiştir. Araştırma konusu ve tasarımının nasıl yapılabileceği konusu üzerine bir dizi tartışma yapılırken bahsedilen düzlemde "seyir amaçlı fiziksel anatomiden seyir amaçl sosyal anatomiye” bir geçiş olduğu sosyal paylaşım ağlarının ise bu anatominin araçları olduğu anatominin artık hekimler tarafından değil sosyal paylaşım siteleri tarafından yapıldığ 1 yönünde yoğun vurguları olmuştur. Akademi programı esnasında bu vurgular temelinde yapılan tartışmalar ve fikir alış verişlerinden sonra çalışmanın seyir amaçlı fiziksel anatomi temasıyla sınırlandırılmayıp "seyir amaçl fiziksel anatomiden seyir amaçl sosyal anatomiye" şeklinde daha geniş bir tema üzerinden tasarlanmasının uygun olacağı düşünülmüştür. Psikiyatristlerin açmış olduğu pencereden yola çıkarak gerçekleştirilen bu tema genişlemesi sayesin- 
de iktidarın zaman içerisinde değişen formlarına yönelik olarak da bir perspektifin ortaya konulmasının mümkün olabileceği düşünülmüştür. Farklı iktidar formları temelinde yapılan böylesi bir analiz aslında biyo iktidar ve biyo politika olmak üzere iki farklı iktidar formunun bireylerin zihin dünyalarını şekillendirerek onları nasıl itaatkâr hale getirdiklerine yönelik bir analizi kapsamaktadır.

$\mathrm{Bu}$ anlatılanlar ışığında tasarlanan araştırmada yukarıda da ifade edildiği gibi 9 psikiyatrist hekimle mülakatlar gerçekleştirilmiştir. Her bir hekimle 3 er defa görüşülmüş ve her bir görüşme ortalama 2 saate yakın sürmüştür. Kimlerle mülakat yapılacağı belirlendikten sonra katılımcılarla gerçekleştirilen birinci mülakatlarda katılımcılara bir iktidar mekanizması olarak seyir amaçlı fiziksel anatomiyle ilgili sorular sorulmuştur. Konu ile ilgili sorular sorulmadan önce geçmişte idam edilen suçlulara o dönemin cerrahları tarafından gerçekleştirilen anatominin halka izletilmesi olayları anlatılmıştır. Böylesi bir izletilme olayının ve o esnada yaşananların izleyen halk üzerinde disipline olma ve itaat etme bağlamında nasıl bir etkisi olduğu ve bu etkinin birey için ne tür sonuçlar doğurduğu hakkında sorular sorulmuştur. İkinci mülakatlarda ise, psikiyatristler tarafindan sosyal anatomi olarak nitelendirilen sosyal paylaşım ağlarında yapılan paylaşımların ve uzmanlar başta olmak üzere farklı toplumsal düzlemden kişilerle kurumların bu paylaşımlara göstermiş oldukları tepkiler temelinde ortaya çıan iklimin, bireylerin disipline olmalarında ve istenilen biçimde davranarak itaatkâr birer ferde dönüşmelerinde nasıl bir rol oynadığına yönelik sorular sorulmuştur. Bu sorular sorulurken araştırmanın yapıldığı dönemde sosyal medyadan yapılan bazı paylaşımlar ve bu paylaşımlara uzmanların, gazetecilerin ve farklı bazı kesimlerin göstermiş oldukları tepkiler örnek verilmiştir.

İfade edilen çerçevede gerçekleştirilen mülakatlar kayıt altına alınmıştır. Ayrıca mülakatlar esnasında yaşananlar ve mülakat yapılan katılımcıların sorulara karşı vermiş olduğu vücut tepkileri verilerin analizi ve yorumlanması esnasında kullanılabileceği düşünülerek araştırmacı tarafından ayrıca not edilmiştir. Kayıt altına alınan her bir mülakat daha sonra araştırmacı tarafından yazıya geçirilmiştir. Bu şekilde her mülakat yazılı bir dokümana dönüştürülmüştür.

\section{Verilerin Güvenvericiliği}

Nitel bir araştırmada verilerin güven-vericiliğinin sağlanmasında farklı bir takım yollar izlenebilir. Bu araştırmada geçerliliğin test edilmesinde doğal olarak araştırma konusunu oluşturan temalar ile bu temalara ait olduğu düşünülen değişkenler arasında nedensellik ilişkisinin düzeyi üzerine odaklanılmıştır. Bu nedenle araştırmacı tarafından belirlenen temalar ve temalara ilişkin değişkenler temel alınarak araştırmacının toplamış olduğu veriler dışında, araştırmaya yön veren temalarla paralellik arz eden temalara ait değişkenlerle ilgili farklı veri setleriyle araştırma temasına benzer farklı şablon ve örneklerle eşleştirmeler yapılması yoluna gidilmiştir. Bu çerçevede anatomi, seyir amaçli fiziksel anatomi ve sosyal anatomi temalarına vurgu yapan iktidar, iktidar ilişkileri ve yönetim üzerine yazılmış kitaplar incelenerek temalarla bu araştırmada belirlenen değişkenler arasında ilişki olduğuna dair eşleştirmeler yapma yoluna gidilmiştir. Burada amaç bu araştırmaya yön veren temaların yine bu 
araştırmada tespit edilen değişkenler üzerinden analiz edilmesinin doğru ve anlamlı olduğuna dair kanıt niteliğinde olan açıklamaları ve bulguları ortaya koyabilmektir. Güvenilirliğin sağlanabilmesi için de benzer şekilde araştırmaya yön veren temalar temelinde yapılan analiz sonuçlarıyla benzerlik arz eden, bu analizleri destekleyen farklı veri ve çıkarımlara vurgu yapılması yoluna gidilmiştir. Bir başka ifadeyle, bu araştırmada araştırmacı tarafından ulaşılan verilerin analizi sonucunda bulgular, farklı veri kaynakları (iktidar, iktidar ilişkileri ve yönetim üzerine yazılmış kitaplar) üzerinden desteklenme yoluna gidilmiştir.

\section{Verilerin Analizi-Bulgular ve Yorumlar}

Araştırmada psikiyatristlerle yapılan mülakatlar ilk olarak araştırmacı tarafından yazıya geçirilmiştir. Daha sonra hem mülakatların sözlü formatları, hem de yazıya geçirilerek dokümana dönüştürülen yazılı formatları mülakat yapılan kişilere gönderilmiştir. Mülakat yapılan kişilerden sözlü ve yazılı mülakat sonuçlarını incelemeleri yazıya geçirilen görüşmelerde yanlış anlaşılan, yanlış ifade edildiği düşünülen alanlar olup olmadığını var ise bu alanların düzeltilmesi yönünde son katkılarını sunmaları rica edilmiştir. Mülakatın gerçekleştirildiği 9 psikiyatrist hekimden 7 tanesi bahsedilen düzlemde bir katkı sunmuştur. İstenilen biçimde katkı sunmayan katılımcıların ifadeleri ise analize dâhil edilmemiştir. Bu durumda 9 psikiyatrist hekimle mülakat gerçekleştirilmiş olmasına rağmen 7 tanesi üzerinden elde edilen veriler analize tabi tutulmuştur. Veri toplama yöntemi olarak mülakatın kullanıldığı nitel bir araştırmada toplanan verilerin analizi için içerik analizinin farklı formları başta olmak üzere mantıksal bir kurgu çerçevesinde alternatif veri analiz metotlarını ve farklı bilgisayar programlarını kullanmak mümkündür. Ancak bu çalışmada hem mülakat yapılan kişilerin sayısının azlığı, hem mülakatlarda sorulan soruların azlığı (araştırma konusuyla doğrudan ilgili 3 soru), hem de verilen cevapların çok kısa ve öz olması nedeniyle katılımcıların ifadelerinden doğrudan alıntılar yapılması yoluna gidilmiştir. $\mathrm{Bu}$ ifadelerin araştırmaya yön veren odakla ilgili olarak çok çarpıcı ifadeler olması da böylesi bir analiz yolunun tercih edilmesinin bir diğer nedenini oluşturmaktadır. Ayrıca doğrudan alıntılar yoluyla "nesnellik" sağlanmaya, yani verilerin ideoloji başta olmak üzere diğer bütün kaygılardan sıyrılarak, bilimsel kaygılar göz önünde bulundurularak incelenmesi-analiz edilmesi sağlanmaya çalışılmıştır.

\section{Seyir Amaçlı "Fiziksel Anatominin" Bireyin Zihin ve Duygu Dünyasında Bulduğu Karşılıkla Bu Karşılığın Bireyin Disipline Olarak İtaatkâr Bir Bireye Dönüşmesi Üzerindeki Etkisine Dair Analizler}

Seyir amaçlı fiziksel anatomi veya bir başka ifadeyle aleni anatomi bireyleri disipline ederek onların uygun görülen itaatkâr bireylere dönüştürülmesinde kullanılan iktidar mekanizmaları olarak nitelendirilmektedir. McNally ${ }^{24}$ de yer alan "aleni anatomi, proleterya bedeni üzerinde sınıf iktidarının bir ayin gibi uygulanması vasıtasıyla burjuva kaygıların dindirmek üzere tasarlanan terbiye amaçlı pratiklere bağhydı" yönündeki ifadesiyle aleni anatominin bireylerin terbiye edilerek istenilen itaatkâr

24 David McNally, Piyasanın Ucubeleri Zombiler Vampirler ve Küresel Kapitalizm, çev., İdil Çetin, İstanbul: Dipnot Yayınları, 2015, s.51. 
bireye dönüştürülme de kullanılan etkin bir değişken/mekanizma olduğu yönündeki tespiti desteklemektedir. McNally ayrıca aleni anatominin beden politiğinin siyasal bir anatomisini oluşturduğunu ileri sürerek yönetici sınıfın idam üzerinden bireylerin yaşamı üzerindeki iktidarını ispat ederek, bedensel teşrihi merkeze alan uzun bir ahlaki eğitim başlattığını ileri sürmektedir. McNally’ye göre aleni anatomide yapılan iş sadece bir insan bedeninin parçalanması değildir. Aleni anatomi esnasında gerçekleştirilen parçalanmayla toplumsal düzen arzu edilen biçimiyle kurulmaktadır. Bu süreçte devlet sembolik olarak yeniden kabul edilmiş ve onaylanmıştır. Toplumsal düzen ön görülen, arzu edilen bir biçimde sağlanmış ve bu düzene uymayanlara karşı gösterilen muamele ile diğer bireylere gerekli mesaj verilmiştir. Kapitalistleşme süreciyle birlikte egemen sınıf, bireyleri kendi amacı doğrultusunda itaatkâr varlıklara dönüştürmek için onları disipline etmek adına yeni cezaevleri inşa etmiştir. Bunun yanı sıra toplumu yeni korkularla donatma yolunda önemli şeyleri uygulamaya geçirmiş ve bunun için de gelişme evresinde olan anatomi hizmetinin de desteğini almıştır. ${ }^{25} \mathrm{Bu}$ ifade edilenler iktidarın disipline etme, bireyleri amaçlanan biçimde davranışa sevk etme konusunda itaatkâr birer varlığa dönüştürme temalarıyla aleni anatomi-anatomi değişkeniyle ilişkilendirilebileceğini bir başka ifadeyle bu araştırmada kurgulandığı biçimiyle "araştırmanın temellendirildiği temayla" "bu temanın ilişkilendirildiği değişken" arasında ön görülen şekilde bir bağlantı olduğunu işaret etmektedir. Bu bağlantıdan yola çıkarak seyir amaçlı aleni anatominin bu anatomiyi izleyen bireylerin duygu ve zihin dünyasında nasıl bir karşılık bulduğunu, bu karşılık bulmayla birlikte bireyde ne tür fikir ve duyguların ortaya çıkabileceği ve böylece izlenenlerin bireyleri nasıl itaatkâr varlıklara dönüştürebildiğine ilişkin bir alana yönelinebilirliğine odaklanılabilir. Mülakat yapılan psikiyatrist hekimlerin bu çerçevedeki ifadeleri şu şekildedir.

P1: "İnsanların bir suçlunun cesedinin hekimler tarafından onların gözü önünde parçalanmasını izlemeleri onlar üzerinde iki temel etki bırakacaktır. Bunlardan ilki bireyin eğer söz konusu konuma kendisi düşerse kendisini bekleyen sona tanıklık ettiği yönündeki korku hissiyatıdır. Bundan dolayıdır ki insan böyle bir sonla karşılaşmamak için çok dikkatli davranacak ve konulan kurallara bu korku nedeniyle uymada büyük özen gösterecektir. Anatominin izlenmesinde insan üzerindeki ikinci etkisi ise böyle bir duruma düşmesinin yakınlarına çektireceği üzüntü ve ıstırap düzeyidir. Suçlu olmakla yakınları için utanç kaynağı olduğu gibi bedenine karşı yapılanların da yakınları için ayrı bir acı kaynağı olacağını düşünmektedir. Dolayısıyla bu iki temel etki bireyi kurallara daha fazla uymaya ve istenilen şekilde davranmaya yönlendirecektir."(18.10.2017 tarihinde yapılan mülakattan yapılan alıntı).

P2: "İdam edilen ya da suçundan dolayı kapatıldığı cezaevinde ölen kişinin halkın önünde tıp bilimine katkı sağlamak amaçlı da olsa yapılan anatomiyi izleyen insanların ilk akıllarına gelen şey korkudur. Bu korku onları birer suçluya dönüştürmemek adına kurallara uymaya motive edecek ve birey kuralları kabul eden itaatkâr bir birey olmak konusunda kendini programlama yoluna 
gidebilecektir."(28.10.2017 tarihinde yapılan mülakattan alınt1).

P3: "Suçluların bedenlerine yapılan anatomi tarihteki en önemli korku salma seansları olarak kabul edilebilir. Bu seansları izleyenler çılgınca çığlıklar atsalar da kendi bedenlerine öyle bir muamele yapılmaması yönünde davranmaya hazır hale gelirler. Ne kendi bedenlerini parçalatmak ne de yakınlarına utanç ve acı vermek istemezler. Bu nedenle kurallara uyma konusunda titiz davranır ve istekli hale gelirler."(30.10.2017 tarihinde yapilan mülakattan alınt1).

P4: "İnsanları istenilen şekilde davranmaya zorlamada ve onları itaatkâr hale getirmede korku, ödül ve cezanın önemli bir yeri vardır. Suçlu bedenine yapılan anatomiyle insanın bir insanın bedeninin parçalanmasını izlemesi onu belli kurallara uymamanın sonucunda kendini bekleyen olası sonu göstermek üzerinden korkutmaktadır. Bu duruma düşmemek için çok daha dikkatli davranacaktır." (30.10.2017 tarihinde yapılan mülakattan alıntı).

P5: "Korku toplumsal düzenin sağlanmasında kullanılan en önemli duygulardan bir tanesidir. Anatomi izletmek anatomiye konu olan bedenin ise kurallara uymayan birinin bedeninin olduğunun bilinmesi kişide korku hissini uyandiracak o sahneler bireyin zihninde hep olacak ve birey böyle bir duruma düşmemek için kendine çizilen sınırlar içerisinde davranacaktır." "(09.11.2017 tarihinde yapılan mülakattan alıntı).

P6: "Bir suçlunun doktorlar tarafından cesedinin parçalanması hem o suçlunun yakınları için büyük bir acı ve utanç hem de diğer insanlar için kendi ve yakınları adına duyacakları büyük bir endişe ve korkuyu harekete geçirecektir. Böyle olmamak için çalışacaklardır." "(12.11.2017 tarihinde yapılan mülakat$\tan$ alint1).

P7: "Cezalandırılma sonucunda çekilen acı ya da mahrum kalınanların etkisi bireyleri korkutmakta ve onları kurallara uyarak arzu edilen şekilde davranmaya itmektedir. Suçluların bedenlerine uygulanan anatomilerin izletilmesi bireylere kurallara uymama konusunda olası ceza ve sonu göstererek onları itaatkâr olmaya yönlendirmektedir." (14.11.2017 tarihinde yapılan mülakattan alınt1).

Psikiyatristlerin yukarıda yer alan ifadelerinden de anlaşılacağı üzere fiziksel aleni anatomi, bu anatomiyi izleyen ve/veya suçlu bedeni üzerinde cerrahlar tarafından böylesi bir anatomi yapıldığını duyan insanların zihninde korku ve utanç olmak üzere iki temel kaygı ortaya çıkarmaktadır. İzleyen ya da duyan insanlar eğer istenilen düzlemde ve düzeyde disipline olmaz ve üretkenlik sürecine katkı sağlamayarak iktidar tarafından istenmeyen yollara saparak suçlu bir bireye dönüşürlerse, kendilerini bekleyen olası sonun böyle olacağını düşünmektedirler. İnsanlar, kendi cesetlerinin de parçalanarak hayvanlara yem olacağını düşünerek ileri düzeyde bir korkuyla disipline mekanizmalarına karşı baş eğmeye yönelmektedirler. Korkunun insan psikolojisi üzerindeki etkisi çok yönlü olabilir. Ancak, iktidar aleni anatomiyle zihinlerde yaratmış olduğu korkuyla onları kendi düzleminde davranmaya yöneltmeyi 
amaçlamaktadır. Aleni anatominin insan zihninde oluşturmuş olduğu ifade edilen bir diğer karşılık ise utançtır. İnsanlar iktidarın öngördüğü düzlemin dışına çıkarak suçlu olmayı tercih ettiklerinde, annelerinin-babalarının, eşlerinin ve çocuklarının kurallara uymayarak adi bir suçlu olan ve cesedi parçalanarak hayvanlara yem edilen bir suçlunun ailesi olarak yıllarca bir utanç ve dışlanmışlıkla toplum içinde yaşamak zorunda kalacakları korkusuyla ortaya çıkan utanç kaynağı olma durumu da insanları disipline etmenin zihinsel arka planını oluşturmaktadır. Psikiyatristlerin yukarıda yer alan ifadelerinden hareketle yapılan bu çıkarım tarihsel süreçteki bazı modeller ve yaşanmışlıklarla da desteklenmektedir. İktidar, aleni anatomi üzerinden oluşturduğu korkuyu sürekli kılmak adına farklı mekanizmalar üretme yoluna gitmiş ve bu doğrultuda sanatı kullanmayı tercih etmiştir. Buradaki amaç disipline olmayı reddeden bir insanın olası sonucunu farklı bir mekanizma üzerinden görsel hale getirerek o korkuyu kalıcı kılmaktır. Bu düzlemdeki gravürlerden bir tanesi 1751 tarihindeki William Hogart’in “Zulmün Mükâfatı” isimli gravürüdür. Gravürde bir ceset (Tom Nero isminde birine ait olan) üzerinde cerrahlar tarafından gerçekleştirilen aleni anatomi konu edinmektedir. Bu gravürde ilk olarak disipline olmayarak suç işlemeyi tercih eden adi suçlunun idam edilmesinde kullanılan cellat urganı teşhir edilmiştir. Aslında burada ceza, idam edilmekle bitmemektedir. Suçluya yönelik cezada suçlunun idam edilmesi sadece bir başlangıçtır. İdam ile başlayan ceza aleni anatomiyle devam etmektedir. Gravürde suçlunun cezalandırılmasının devamında anatomi esnasında anatomiye konu olan suçlu bedeninin iç organları bir fıçıya atılmakta ve o esnada fıçıdan sarkan iç organı parçaları bir köpek tarafında yenmektedir. Suçlunun cezası bedeninin bir köpek mamasına dönüştürülmesiyle devam etmektedir. Hatta Hogarth’ın bu gravüründe hükümlünün kalbi köpeğe yem olarak sunularak suçlu en ağır şekilde cezalandırılmaktadır. (Kalbin bu şekilde köpeğe yem olarak sunulmasının ayrı bir sembolik önemi bulunmaktadır. Bilindiği gibi kalp insan yaşamının en hayati organı ve yaşamın odak noktasıdır. Ayrıca, duygusal ve disiplinsel bütün alanların atfedildiği yerdir. Suçlu kalbi kötülüklere gömülmüş ve taşlaşmış kötü bir kalp olarak köpeklere sunulmayı hak etmiştir. ) Gravürde yasalara aldırmayarak onları çiğneyenler bir köpeğin bünyesine girerek hayvanlaştırılmaktadır. Gravürde idam edilen suçlunun kafası ise bir kasnağa yerleştirilmiş bir teşhir mekanizmasıyla yükseltilmiştir. Böylece "eğer bir cani isen acı ölümden sonra da devam etmektedir” önermesi işlenmektedir. Anatominin gerçekleştirildiği yer olan cerrahlar locasında kraliyet iktidarının nişanları her şeyin üzerinde sallanmaktadır. Gravürde görsel olarak tasvir edilen nişanlar, taht ve anatominin gerçekleştirildiği ortam "anatomiyi" devlet iktidarı uygulamasına bağlayan semboller olarak kabul edilebilir. ${ }^{26}$ Burada semboller üzerinden iktidar aslında "insan oğluna" nereye yönelmesi ve ne yapması gerektiğini göstermektedir. Benzer örüntü ve imaları Dr. Tulp’un Anatomisi isimli gravürde görmek de mümkündür. Dr. Tulp’un gravüründe 1632 yılı Hollanda'sında yapılan bir anatomi, bu anatomiyi izlemek için para ödeyen bir grup elitle birlikte resmedilmiştir. Bu gravürde Hogart'in gravüründen farklı olarak ceset bir mekanizma aracılığ 1 ile idare edilmekte ve yoksul suçlunun bedeni bir üre-

26 McNally, Piyasanın Ucubeleri s.83-84. 
tim aracı olan makasa tabi kılınmaktadır. ${ }^{27}$ Bahsedilen bu iki gravür başta olmak üzere iktidarın öngörüleri doğrultusunda ortaya çıkan diğer mekanizmaların çeşitli şekillerde izlettikleri korku sahnelerini aleni sahneler olmadan da korku, dehşet ve utancı sürekli zihinlerde tutmak üzere önemli bir işlev gördükleri söylenebilir. Hem psikiyatristlerin açıklamaları hem de bu açıklamaları destekleyen diğer alıntılar temelinde bir özetleme yapmak gerekirse, iktidar aleni anatomiyle insan zihinlerde kalıcı korkular oluşturarak onların disipline edilmiş itaatkar bireylere dönüşmelerini sağlamaya niyetlenmiştir.

Aleni fiziksel anatomi üzerinden bireyin itaatkâr bir yapıya dönüştürülmesi esnasında iktidar kendini gizlemek için "tıp bilimini" kullanmaktadır. Bir başka ifadeyle, iktidar icat ettiği iktidar makinesinin kimseler fark etmeden niyetlenen sonuçlara ulaşması için bir tabi kılma biçimi olan cerrahları kullanmaktadır. Bu kullanımla iktidarın kendini gizlemek için geliştirmiş olduğu üst söylem ise insanların hastalıklarının tedavilerinin geliştirilmesi için anatominin cerrahlara kazandırdığı bilginin önemine dairdir. Bu söylem üzerinden iktidar insan sağllğına katkı yapma çabalarına yönelik bir algı oluşturarak öteki niyetini (itaatkar bireyler oluşturma) gizlemeyi başarmaktadır.

\section{Sosyal Medya Aracılığıyla Gerçekleştirilen "Sosyal Anatominin" Bireylerin Zihin Dünyasındaki Karşılığı ve Bu Karşılığın Bireyin İtaatkâr Bir Bireye Dönüşmesindeki Etkisi: Sosyal Medyanın Bir İktidar Aracına Dönüz̧ümünün İzleri}

Araştırmanın önceki kısımlarında da ifade edildiği gibi bu çalışma ilk olarak tarihsel süreçte cerrahlar tarafından suçluların bedenleri üzerinden gerçekleştirilen aleni anatominin bireylerin disipline edilerek itaatkâr birer bireylere dönüşmelerinde nasıl bir rol oynayarak etkin bir iktidar aracı işlevi gördügünü ortaya çıkarmak amacıyla tasarlanmıştır. Ancak psikiyatristlerin sosyal medya üzerine vurgularıyla "bir sosyal anatominin" gerçekleştirildiği yönündeki vurguları "aleni fiziksel anatominin" iktidarın formlarının değişmesiyle neoliberal dönemde sosyal medya üzerinden işlerlik kazanan yeni iktidar mekanizması olan "sosyal anatomiye" evrildiği yönünde bir dizi imalar tespit edilmiştir. Bu imalar üzerine yapılan inceleme, sosyal medya aracilığıyla bireyi disipline etmede kullanılan yeni bir anatomi biçiminin ortaya çıkmış olduğuna işaret ederek bu imaları desteklemektedir. Neo liberalizmle birlikte form değiştiren kölelik biçimlerinin nihai hali genelleşmiş kölelik olarak nitelendirilmektedir. Neo liberal dönemin iktidar aygıtları bireyi itaatkâr bir birey haline getirmenin ana niyetsel noktasını oluşturan fabrikanın çok ötesine geçerek bütün yaşamı kaplar hale gelmişlerdir. Bir başka ifadeyle, liberal dönemde ortaya çıan yeni toplumsal ve teknik makinelerle bu makineler temelinde işlerlik kazanan sistemler (sosyal ağlar gibi) bireyi sadece kişisel emeğini kapitalist üretim süreçlerine etkin katılımını sağlamak üzere değil, genel anlamda günlük hayattaki tavır ve davranışlarını da hedef alarak "onu-bireyi" bütünüyle iktidarları altına almaktadırlar. Bu durumda motorize

27 McNally, Piyasanın Ucubeleri. 
makinelerden sonra sibernetik ve enformasyonel makinelerin bireyi çok yönlü tahakküm altına alan yeni bir iktidar çağı ortaya çıkardıkları söylenebilir. ${ }^{28}$

Lazzarato'nun Deleuze ve Guattari'den hareketle ifade ettikleri, araştırmanın veri toplama süreci esnasında psikiyatristlerin sosyal medyanın bir iktidar aygıtı olarak önemli bir işlev gördüğü yönündeki ifadelerini desteklemektedir. Bir iktidar aygıtı olarak sosyal medya psikiyatristlerin ifadelerinde bireyi yönetme ve onu bütün yönleriyle disipline etme konusunda önemli bir işlev üstlenmekte ve paylaşımlar aracıl1ğıyla birey sosyal yaşantısını bütün yönleriyle gözler önüne sermekte bunu bazen görsel araçlar, bazen açık ve net cümleler bazen de dolaylı ifadelerle yapmaktadır. Sosyal medya aracılığıyla bireyin yaşantısının alenileşmesi tarihsel süreçte gerçekleştirilen aleni fiziksel anatomiyle niyetsel olarak paralellik arz etmektedir. Psikiyatristlerin bu yöndeki ifadeleri şu şekildedir.

P1: "Sosyal medyanın bugün geldiği nokta bireylerin davranışları ve düşünceleri üzerinde en fazla etki bırakan yapı olduğudur. Hem bireylerin kendilerinin, hem farklı meslek uzmanlarının yapmış oldukları paylaşımlar hem de bu paylaşımlara gösterilen tepkiler beğenme, nefret, dışlama ve hor görme gibi insani tepkisel biçimler üzerinden bireyin düşünce ve davranışlarını etkilemektedir. Birey, sosyal medya aracılığıyla bir yönüyle farkında olarak, diğer yönüyle de sözleriyle bilinçaltını yansıtarak kendi yaşamını alenileştirmektedir. $\mathrm{Bu}$ alenileştirmeye gösterilen diğer sosyal medya tepkileri bütün kullanıcılara belli yönlerde davranma üzerinde etkili olabilmektedir"(28.10.2017 tarihinde yapılan mülakattan alıntı).

P2: "Sizin bahsettiğiniz ve dile getirdiğiniz bir fiziksel anatominin bugün gelinen noktasının teknoloji aracılı̆̆ı ile insanların gönüllü olarak kendi kendilerine gerçekleştirdikleri yaşamlarını neredeyse bütün yönleriyle seyre koydukları yeni bir durum buna sosyal yönler anatomisi diyebiliriz. Sosyal paylaşım siteleri aracılığ 1 ile insanlar kendi yaşamlarına ait karelerle ilgili görsel ve hissiyatlarını ifade eden yazılar paylaşmaktadır. Bu paylaşımlara diğer sosyal medya kullanıcıları olumlu ya da olumsuz tepkiler göstermektedirler. Bu tepkiler ilgili dönemde ve toplumda neyin iyi neyin kötü olduğuna dair ölçüyü belirlemekte ve bu ölçü üzerinden beğenme, takdir edilme, popüler olma ve dışlanma tanımlamaları üzerinden insanların davranış kalıpları ve davranış biçimleri üzerinde etkili olmaktadır. Ayrıca çeşitli kurumlar ve uzmanlar sosyal paylaşım siteleri vasıtasıyla her an insanların davranışları etkileme ve yönlendirme imkânına sahip olmaktadır” (14.11.2017 tarihinde yapılan mülakattan alintı).

P3: "Sosyal medyanın bugün için insanların yaşamlarını alenileştiren ve insanın kendi eliyle kendi niyetiyle gerçekleştirdiği bir gözler önüne serme, bir görünür hale getirme yani yeni bir anatomi biçimi olduğu görülmektedir.

28 Gilles Deleuze ve Félix Guattari, A Thousand Plateaus, çev., Biran Massumi, Minneapolis: University of Minnesota Press, 1987, s.458. akt. Maurizio Lazzarato, Göstergeler ve Makineler, Çev., Ferda Nur Demirci, İstanbul: Otonom Yayıncılık, 2016, s.34. 
İnternet üzerinden paylaşımlarla birey kendi yaşamına ilişkin kareleri tüm insanların seyrine sunmakta ve seyir edilen bu karelere gelen tepkiler diğer medya aracılığıyla birleşerek olumlu ya da olumsuz tepkiler üzerinden insan davranışlarını etkiler hale gelmektedir. Sosyal medyayla ulaşılan popülerlik, beğeni alma veya tepkiler nedeniyle ötekileştirme biçimleri insanları belli yönde kalmaya itmektedir” (19.11.2017 tarihinde yapılan mülakattan alıntı).

P4: "Sosyal medya insan yaşamına ilişkin farklı kısımların gün yüzüne çıkmasında gönüllü olarak kullanılan önemli bir aygıt olmuştur. Bu yönüyle ilgili sitelerinde yapılan paylaşımlara gösterilen tepkimeler ya bir moda ortaya çıkartarak ya da dışlama ve hor görme eğilimleriyle insanların davranışlarını etkileme özelliğine sahiptir. Ayrıca sosyal medya bugün insanların ne giymeleri ve giymemeleri, ne yapmaları ya da yapmamaları gerektiği veya ne yemeleri ya da yememeleri gerektiği üzerinde de uzmanlar aracılığg ile yapılan paylaşımlar üzerinden son derece etkili olmaktadır." (09.12.2017 tarihinde yapılan mülakattan alınt1).

P5: "Facebook, Twitter ve diğer paylaşma platformları insanların kendi yaşamlarından önemli kesitleri açık ettikleri alanlar haline gelmişlerdir. Bu platformlarda gerçekleştirilen paylaşımlar önce özel takipçiler daha sonra da diğer medya araçları aracılığı ile bir anda toplumsal gündeme oturabilmekte ve gösterilen tepkilerle bir anda insanları bir şeylere yapmaya iten akımlara veya insanlara korkutan bir dizi çekincelere neden olabilmektedir. Ancak sosyal platformların insanlara herkes için ulaşma ve onları etkileme konusunda bizim gibi profesyoneller için de önemli fursatlar sunduğunu unutmamak gerekir. Birçok profesyonel sosyal medya aracılığ i ile insanlara ulaşabilmekte ve onları etkilemektedir." (12.12.2017 tarihinde yapılan mülakattan alıntı).

P6: "Daha önce görüşme yaptığınız meslektaşlarımın görüşlerine tamamen katılıyorum. Sosyal medya bir yaşamsal anatomi aracına dönüşmüştür. Birey kendi sırlarını bilerek ya da bilmeyerek bu kadar gönüllü açığa çıkartmaya sanırım tarihin hiçbir döneminde bu kadar istekli olmamıştır. Sosyal medyada yapılan paylaşımlara gösterilen tepkiler bireyde bir davranışı yapma ya da yapmama konusunda çok önemli bir işlev üstlenmektedir. Sosyal medyanın bu rolü onu insan davranışlarını etkileyen önemli bir araca dönüştürmektedir. Ayrıca artık birey sosyal medya üzerinden takipleriyle ne yiyeceğine, ne yapacağına ve nasıl giyineceğine kadar etkilenebilmektedir." (18.12.2017 tarihinde yapılan mülakattan alıntı).

P7: "Sosyal medya paylaşımların bir sosyal anatomi olarak nitelendirilmesi fikri evet eğer anatomi bilinmeyeni parçalamak ve açmak olmadan bilmenin görmenin mümkün olmadığı durumları gösterir hale getirmek şeklinde yorumlanırsa doğru. Paylaşımlar diğer insanların başka şekilde bilmelerinin mümkün olmadığı durumları ve anları bireyin kendi isteği ile görünür hale getirdiği durumlardır. Bu durumlara diğer insanlar ve uzmanlar tarafından gösterilen tepkilerle yargılamalar ise bütün insanları etkileme özelliğine sahip 
bazı dalgalar oluşturabilmektedir. Siyasal ve sosyal anlamda birçok gelişme bu durumu desteklemektedir. (Bahar devrimlerine vurgu yapıyor). Ayrıca sosyal medya uzmanlık bilgisine ulaşma üzerinden de insan davranışlarını etkilemektedir. Sosyal medya üzerinden beğenilmek, takdir edilmek ve bu yolla değer kazanmak bireylere ne yapmaları ve ne yapmamaları gerektiğini öğütlemektedir" (18.12.2017 tarihinde yapılan mülakattan alıntı).

Psikiyatristlerin yukarıda yer alan ifadeleri temel alındığında, sosyal medyanın neoliberalizmle birlikte ortaya çıkan iktidar biçiminin etkin araçlarından biri olduğu söylenebilir. Yukarıda yer alan ifadeler temel alındığında sosyal medyanın bir iktidar aracı olarak üç temel işlev üstlendiği söylenebilir. Bunlardan ilki, kişilerin bizzat kendi istekleriyle kendi sosyal ve özel yaşam alanlarını seyire açmalarıdır. Kişilerin kendi inisiyatifiyle seyre açılan sosyal ve özel yaşam alanlarıyla eylemler diğer sosyal medya kullanıcıları ve iktidarın bir diğer mekanizması olan profesyoneller aracılı̆̆ ile "değerlendirilmekte, yargılanmakta ve beğenme, kınama, dışlama veya bir salgına dönüştürerek moda haline getirme” gibi ceza ve ödül alanlarına sokulmaktadırlar. Kişinin sosyal ve özel yaşama ilişkin alenileştirmeleri hem kişinin hayatındaki diğer paydaşlar hem de iktidarın diğer disipline etme ve tabi kılma unsurları olan profesyoneller tarafından beğenildiğinde, kişinin paylaşımına konu olan eylem ve/veya düşünce bireyin popülerleşmesi üzerinden paylaşımı yapan kişiyi ödüllendirirken, diğer yandan da toplumdaki diğer bireylere ne yapmaları ve nasıl yapmaları durumunda benzer bir ödüllendirmeye layık olacaklarına işaret etmekte ve popülerleşme üzerinden neo-liberal iktidar formuna özgü bir isteklendirme yapılmaktadır. Sosyal medyanın bir iktidar aracı olarak üstlenmiş olduğu ikinci işlev ise cezalandırma ve dışlama biçimleri üzerinden işlemektedir. Hakim iktidarın ön gördüğü davranışsal ve düşünsel formun dışına çıkarak disipline olmayı ve öngörülen formu almayı reddeden bireye özgü davranışın paylaşımına hem diğer insanlar hem de iktidara özgü tabi kılma mekanizmalarının temsilcileri olan profesyoneller yoğun bir tepki göstermektedirler. Gösterilen bu tepkiler aracılığıyla birey bir yandan ilgili düşünsel ve davranışsal formu ortaya koyan biri olarak yargılanarak mahkûm edilmekte, diğer yandan da dişlama başta olmak üzere diğer sosyal cezalarla bir utanç abidesine dönüştürülmektedir. Bu şekilde de diğer toplumsal düzlemlere nasıl davranılmaması gerektikleri yönünde etkin bir izlek sunulmaktadır. Sosyal medyanın bir iktidar arac1 olarak üstlendiği üçüncü işlev ise, iktidarın hükmetme biçimlerinden biri olarak kabul edilen tabi kılmalar aracılığıyla ortaya çıkan ve bireyler tarafindan uzun bir uğraşın sonunda ulaşılan profesyonel meslek mensupları üzerinden işlerlik kazanmaktadır. Lazzarato'ya göre, profesyonel meslek mensupları, bir anlamda toplumsal tabi kılmalar sonucunda ortaya çıkmış olan ve iktidarın inşa ettiği, sağlıklı bir şekilde işlemesi için gerekli kurguyu yaptığ toplumsal makineyi işletecek olan bürokratlar, doktorlar, öğretmenler, diyetisyenler gibi profesyonellerdir. ${ }^{29}$ İktidarın inşa ettiği ve çalışması için gerekli kurguyu yaptığı toplumsal makineyi işletme rolünü üstlenen bu profesyoneller hem kişilerin kendi arzuları ile gerçekleştirdikleri yaşamsal alenileştirmeye getirmiş oldukları yorumlar, yargılamalar ve diğer tepkilerle hem de ken-

29 Lazzarato, Göstergeler ve Makineler, s.35. 
di uzmanlık alanları içine giren konularla ilgili olarak yapmış oldukları paylaşımlarla insanları iktidarın ön gördüğü düşünsel ve davranışsal formun içinde tutmada etkin rol almaktadırlar. Bireylerin kendileri tarafından yapılan sosyal alenileştirme, iktidarın kurguladığı toplumsal makineyi çalıştıran bu profesyoneller tarafından sosyal bir anatomiye dönüştürülerek bireye özgü yaşamsal alanlar, paylaşımı yapan bireyin hiç aklına gelmeyecek biçimde incelenmekte, didik didik edilmekte ve bu inceleme sonucunda verilen hükme göre toplumun arzu edilen düzleme girmesine yönelik bir söylem oluşturulmaktadır. Psikiyatristlerin yukarıda yer alan ifadelerinden yapılan bu çıkarımları destekler farklı vurguların da var olduğu görülmektedir. Bilindiği üzere iki temel heterojen iktidar aygitından bahsedilmektedir. Bunlardan ilki toplumsal tabi kılma, ikincisi ise makinesel kölelik. Makinesel kölelik toplumsal tabi kılmadan oldukça farklı işleyen bir mekanizmadır. Makinesel kölelikte birey toplumsal tabi kılmadan farklı olarak artık bireyselleşmiş özne, ekonomik özne veya vatandaş olarak kurgulanmamakta, tüm bunlardan farklı olarak birey şirket asamblajı, finans asamblajı, medya asamblajı ve onun kolektif kurumlarının (okullar, hastaneler, müzeler, televizyon, internet gibi) içerisinde bir dişli, bir çark ve tamamlayıcı bir parça olarak düşünülmektedir. Burada makinesel köleliğin teknoloji tarafından desteklenen bir komuta, düzenleme ve yönetme tarzı olduğu görülmektedir. ${ }^{30} \mathrm{Bu}$ ifade edilenlerin yanında sosyal medyanın sosyal anatomi üzerinden işleyen bir iktidar aracı olarak işlev üstlendiğine ilişkin en önemli açıklama yine Foucault’un vurgularında kendini göstermektedir. Foucault'un iktidar kavramına ilişkin "iktidar her yerdedir, her yeri kapsadiğı için değil, her ilişki ve her düzlemden doğabildiği için her yerdedir" yönündeki açıklamaları doğal olarak amaçlı bir şekilde kullanılma özelliği olan her şeyi bir iktidar aracı olarak nitelendirmektedir. Buraya kadar ifade edilenleri temel alarak özetlemek gerekirse, sosyal medya farklı işlevler üzerinden işleyen önemli bir iktidar aracı olarak nitelendirilmektedir. Bireyin kendi isteğiyle gerçekleştirmiş olduğu aleni sosyal anatomi aracilğgla alenileşen düşünce ve davranışlara gösterilen tepkiler toplumsal bir hiza verme ve disipline etme faaliyetine dönüşmektedir. Ön görülen formun dışında düşünenler ve davrananlar hem iktidarın inşa ettiği makineyi çalıştıran profesyoneller hem de disipline olmayı idealize etmiş bireyler tarafından hemen yargılanmakta ve mahkûm edilerek dışlanmaktadırlar. Böylece sosyal medya, bir anlamda iktidarın icat ettiği makineyi çalıştıran profesyoneller ve iktidarın ön gördüğü şekilde disipline olmayı idealize edilmiş bireyler tarafından bütün bireyleri iktidarın uygun gördüğü asamblajlardan birine yerleştirerek o düzlemde kalması konusunda önemli bir iktidar aracı olarak işlev görmektedir. Sosyal medya paylaşımları üzerinden gerçekleştirilen sosyal aleni anatominin sonuçlarının bireylerin zihinlerinde bulduğu karşılık ise fiziksel aleni anatominin insanların zihinlerindeki karşılığından çok daha derin ve çok daha fazla yönlü olduğu söylenebilir. Psikiyatristlerin yukarıda yer alan ifadeleri temel alındığında, sosyal medya paylaşımlarının didik didik incelenmesi sonucunda bireylere diğer insanlar ve iktidar makinesini işleten profesyoneller tarafından gösterilen tepkiler beğenilme ve takdir edilme, beğenilme üzerinden popülerleşerek maddi-manevi kazanımlar sağlama veya tersi duygular olan dışlanma, aşağılanma ve sosyal olarak mahkûm edilme gibi korkuların harekete geçmesine neden olmaktadırlar. Fiziksel aleni anatominin zihinsel karşıllı̆ının korku 
ve utanç olduğu göz önüne alındığında, sosyal aleni anatominin zihinsel karşılığının çok daha boyutlu olduğu rahatlıkla söylenebilir. Ayrıca, iktidar makinesinin çalışmasina hizmet eden profesyonellerin sağlık, spor, güzel görünme, verimliliği arttırma ve beslenme üzerine uzmanlık bilgilerini temel alarak gerçekleştirmiş oldukları niyetli paylaşımlar da göz önüne alındığında, sosyal medyanın Foucault’un ifade ettiği gibi nüfuzlar/nüfuz etme olarak karşımıza çıktığı söylenebilir. Sosyal medya üzerinden gerçekleştirilen profesyoneller uzmanlık bilgisi paylaşımlarıyla bireyin bedeni başta olmak üzere bütün yaşamsal alanına nüfuz eder hale gelmiştir. Birey en kolay yoldan etkilenebilen ve yön verilebilen bir alana çekilmiştir.

Bahsedilen biçimde gerek sosyal aleni anatomi gerekse profesyoneller tarafından gerçekleştirilen paylaşımlar üzerinden bireye hükmetme olayında ise iktidar kendisini yine tıp, hukuk, spor ve ekonomi biliminin argümanları üzerinden inşa ettiği söylem temelinde gizlemeyi başarmaktadır. Bir başka ifadeyle iktidar, kendini gizleme konusunda bilim kurumuna ve bu kurumun temsilcilerinin açıklamalarına sığınmaktadır. Ancak iktidarın sosyal anatomi temelinde kendini gizleme mahirliği önceki dönemlerde çok daha başarılı ve çok daha etkileyicidir. Gelinen noktada artık birey kendi isteği ile kendi yaşam alanını alenileştirmekte ve derinlemesine incelenmesine razı olmaktadır. Ayrıca birey profesyoneller tarafından iktidarın ön görülen formuna sokulma konusunda söylemin izini sürmekte ve bu konuda gereken bütün argümanlara en kısa yoldan ulaşıyor olmaktan da memnun olmaktadır. Yani gelinen noktada birey "disipline olmayı", kapitalist sistemin ön gördüğü formlara girmeyi ve orada yol almayı kendi rızasıyla kabul eder hale gelmiştir.

Aslında sosyal medya tarafından gerçekleştirilen ve bireyin kendi yaşamının başkaları tarafından didik didik edilmesi ve yargılanmasıyla sonuçlanan aleni "sosyal anatomi” boyutuyla ilgili olarak tarihsel süreçte önemli oranda benzer işleyen bir başka mekanizma daha olduğu görülmektedir. Hristiyanlık inanç sisteminin en önemli ritüellerinden biri olan "günah itirafi" mekanizması da bireyin kendi isteğiyle gerçekleştirmiş olduğu bir sosyal anatomi örneği olarak kabul edilebilir. Günah çıkarma itirafı, Hristiyanlığa özgü en önemli kutsal gizemlerden bir tanesi olarak kabul edilmektedir. Bu ritüelde tövbe eden kişi itiraf etmiş olduğu her günah için gizem sayesinde Mesih'in Tanrısal affına nail olmuş olur. İtiraf bireysel olarak papaza veya keşişe yapılmaktadır. İtiraf mekanizmasıyla birey kendi yaşamının özel alanlarını iktidar temsilcisi olan papaza ya da keşişe belli kurallar eşliğinde sunmaktadır. Kişinin özel yaşamı itirafın yapıldığ 1 otorite tarafından sorulan sorularla detaylandırılmaktadır. Bu rituel temel alındığında, itiraf mekanizmasının bireyi "affetme" "uygun görülmeyen davranışı bir daha yapmama” vurguları üzerinden disipline ederek bireyin ön görülen formda tutulma konusunda bir araç olarak kullanıldığı söylenebilir. Özetlemek gerekirse, "İktidar temelli bir değerlendirmede" hem fiziksel anatomi hem de sosyal anatomi alenileștirme üzerinden işleyen bir sistem aracılığı ile insanları iktidarın ön gördüğü forma sokmada oldukça etkin kullanılan birer iktidar mekanizması olarak görülmektedir. Aradaki fark aleni fiziksel anatominin cerrahlar, sosyal anatominin ise önce papazlar ve keşişler daha sonra da iktidarın icat ettiği makineyi çalıştıran profesyoneller (doktorlar, psikologlar, bürokratlar, hukukçular) tarafından yapılmış ve yapılıyor olmasıdır. 


\section{Sonuç: Bir İktidar Aracı Olarak Seyir Amaçlı (Aleni) Fiziksel Anatomiden Sosyal Anatomiye: Proleterya Bedeni Üzerinden Sermaye Sınıfının Form Değiştiren İktidarının Hikayesi}

Kapitalist sistemin ön görülen biçimde işlemesinde ve sürekliliğinin sağlanmasında en önemli iki temel iktidar unsuru toplumsal tabi kılma ve makinesel köleliktir. Bu iki mekanizmaya ek olarak bu süreçlere ait görünen ve görünmeyen semiyotiklerin de kapitalizmin başarısında önemli bir yeri bulunmaktadır. ${ }^{31}$ Hem fiziksel hem de sosyal aleni anatomi, hem iktidar tarafından oluşturulan makinenin çalışmasını sağlayan toplumsal tabi kılmaların, hem de makinesel kölelik işleyişlerinin kesişme alanlarında bulunan ve insanların disipline edilerek iktidarın ön gördüğü forma veya asamblaja sokulmasında oldukça önemli işlev üstlenen bir araç olarak görülmektedir. Araştırmada iktidar tarafından inşa edilen makinenin ön görülen biçimde çalışmasında önemli işlev üstlenen psikiyatristler üzerinden toplanan veriler hem aleni fiziksel hem de sosyal anatominin bireylerin zihninde oluşturdukları korku, utanç, beğenme, dışlanma, hor görülme ve reddedilme unsurları üzerinden bireyleri iktidarın ön gördüğü forma sokma konusunda etkin birer araç alarak kullanıldığını göstermektedir. İktidar teması üzerine açıklamalar seti geliştiren diğer düşünürlerin imaları da psikiyatristler üzerinden yapılan bu tespitleri desteklemektedir.

Sosyal aleni anatomide ise iktidar aleni fiziksel anatomiden farklı olarak çok daha ileri düzeyde bir alana hükmetmeye niyetlenmiş ve hem sosyal medya kullanıcılarının tamamını hem de iktidar makinesini çalıştıran bütün profesyonelleri bu yolda etkili bir şekilde kullanmayı başarmıştır. Sosyal medya bir iktidar aracı olarak, hem anatomiyi konu alan paylaşımları bireyin kendi rızasıyla ortaya çıkartarak hem de profesyonellerin uzmanlık bilgilerini hayranlıkla takip eden bir halk kitlesi yaratarak kendi arzu ettiği forma insanları sokmada son derece etkilidir. Bir başka ifadeyle, sosyal medya, iktidarın yaşamın bütün alanlarına kendini gizleyerek nüfuz etmesini sağladığı en önemli araçlarından biri haline gelişmiştir. Gelinen son noktada hem iktidarın etki alanı derinleşmiş hem de iktidar kendi sürekliliği için elzem olan gizliliği sağlama konusunda mahirliğini geçmişle mukayese edilmeyecek oranda arttırmıştır. Ayrıca çalışmada elde edilen bulgular, kendini gizleme zorunluluğu olan bir başka ifadeyle kendini gizlemeyi başardığı ölçüde başarılı olan iktidarın, kendini gizleme konusundaki mahirliğinin sosyal anatomiyle birlikte arttığını ve bu yolla toplumsal düzlemdeki bütün ilişkilere sızma konusunda kendine daha rahat işleyen yollar inşa edebildiğine işaret etmektedir.

\section{Kaynakça}

Akgündüz, Gülay Özdemir. “Foucault'da İktidar ve Beden İlişkisi”. Akademik Bakış Dergisi. 38 (2013): 1-16.

Çelebi, Vedat. "Michel Foucault’da Bilgi İktidar ve Özne İlişkisi”. Sosyal ve Beşeri Bilimler Dergisi. 5/1 (2013): 512-523.

Foucault, Michel. Özne ve İktidar. Çev., Işık Ergüden, Osman Akınhay. Ayrıntı Yayınları, 2014. 
Foucault, Michel. Cinselliğin Tarihi. Çev., Hülya Uğur Tanrı̈ver. İstanbul: Ayrıntı Yayınlar1, 2012.

Foucault, Michel. Deliliğin Tarihi. Çev., Mehmet Ali Kılıçbay. İstanbul: İmge Yayınevi, 2014.

Guattari, Felix. Kaçış Çizgileri. Çev., Işık Ergüden. İstanbul: Otonom Yayıncılık, 2014.

Kızılaslan, Aydın, S. Levent Zorluoğlu, Ali Yücel ve Mustafa Sözbilir. "Yeti Yitimi Modellerinin Tarihsel Gelişimi”. İzzet Baysal Üniversitesi Eğitim Fakültesi Dergisi. 16/1 (2015): 183-197.

Lazzarato, Maurizio. Göstergeler ve Makineler. Çev., Ferda Nur Demirci. İstanbul: Otonom Yayıncilik, 2016.

McNally, David. Piyasanın Ucubeleri Zombiler Vampirler ve Küresel Kapitalizm. Çev., İdil Çetin. İstanbul: Dipnot Yayınları, 2015.

Palancı, Cihan. "Biyo-iktidarı Siponaza ile Okumak". Toplum ve Demokrasi. 10/21 (2016): 13-21.

Revel, Judith. Güncelliğin Bir Ontolojisi. Çev., Kemal Atakay. İstanbul: Otonom Yayıncilık, 2006.

Uluğer, Çağrı. "Yaşam ve Ölüm Arasında Sallanan İktidar Sarkacı: Biyo Politika". Mesele Dergisi. 88 (2014): 49-53. 
İNSAN\&İNSAN, Yl1/Year 5, Sayı/Issue 18, Güz/Fall 2018, 317-340

DOI: https://doi.org/10.29224/insanveinsan.427986

\title{
As A Power from (Open) Physical Anatomy to Social Anatomy: The Form- Changing Story of the Power on the Human Body
}

\author{
ALİ TAŞ / OĞUZHAN ÖZTÜRK / UMUT ORHAN
}

\begin{abstract}
In the context of Foucault's statement about power, the aim of this research is to trace how the physical and social anatomy play a role in transforming people into obedient persons. In this framework, it is focused on the question of which human emotions that power mechanisms have built mental background turn people into obedience. Another focal point of this research is to consider how the power in need of concealing itself can achieve its goal of concealing itself successfully. The data were collected through interviews with nine psychiatrist. The data indicate that "physical anatomy" through fear and embarrasment, "social anatomy" through favour, popularity and exlusion feellings have important functions as effective instruments of power. Another finding is that science plays an active role in concealing itself and that by social anatomy, power is both augmenting the domain of individual domination and achieving a more subtle skill in concealing itself.
\end{abstract}

Keywords: Social Power, Foucault, Physical Anatomy, Social anatomy. 